Jurnal Psikologi Teori dan Terapan

2014, Vol. 5, No. 1, 7-14, ISSN: 2087-1708

\title{
Aktualisasi Diri dan Persepsi Terhadap Pelaksanaan Pelatihan Pada Karyawan PT. Pelindo
}

\author{
Ellyana Pratika, dan Ni Wayan Sukmawati Puspitadewi \\ Program Studi Psikologi Universitas Negeri Surabaya
}

\begin{abstract}
This study was aimed to determine the relation between self-actualization and the perception of employees' training implementation in PT Pelindo III Gresik branch. This study method was a correlational research. The subjects were 46 employees of PT Pelindo III Gresik branch. Data collected using self-actualization and perception of training implementation Likert scale. Data analysis technique used in this study was Pearson correlation product moment with the help of SPSS 16 for windows. The result shows that the significant value $(p)$ is 0.000 , while the value of the correlation $(r)$ is 0.651 . The result shows that the significance value of the correlation is less than $0.05(p=0.000<0.05)$ which means the hypothesis of this study is significantly proven. It can be concluded from the result there is a significant relation between self-actualization and the perception of employees' training implementation in PT Pelindo III Gresik branch.
\end{abstract}

Key words: self-actualization, training, employees

\begin{abstract}
Abstrak: Penelitian ini bertujuan untuk mengetahui hubungan antara aktualisasi diri dengan persepsi mengenai pelaksanaan pelatihan pada karyawan PT Pelindo III Cabang Gresik. Penelitian ini merupakan tipe penelitian korelasional. Subjek penelitian ini adalah karyawan PT Pelindo III Cabang Gresik. Jumlah subjek penelitian ini sebanyak 46 karyawan. Pengumpulan data menggunakan kuesioner aktualisasi diri dan kuesioner persepsi mengenai pelaksanaan pelatihan, kuesioner ini menggunakan skala likert. Teknik analisis data dalam penelitian ini adalah teknik analisis korelasi "Pearson product moment" dengan bantuan program SPSS 18 for windows. Berdasarkan hasil analisis data yang diperoleh variable aktualisasi diri dan persepsi mengenai pelaksanaan pelatihan adalah $p=0,000$ sedangkan nilai korelasinya sebesar $(r=0,651)$. Hal tersebut berarti $p$ lebih kecil dari $0,05(p=0,000$ $<0,05)$. Hasil tersebut menunjukan bahwa ada hubungan yang signifikan antara aktualisasi diri dengan persepsi mengenai pelaksanaan pelatihan pada karyawan PT Pelindo III Cabang Gresik. Dengan kata lain, hipotesis dalam penelitian ini diterima.
\end{abstract}

Kata Kunci: Aktualisasi diri, pelatihan, karyawan

Setiap perusahaan harus memiliki karyawan-karyawan yang kompeten agar dapat mencapai tujuan perusahaan. Karyawan yang kompeten tentunya tidak dapat langsung terbentuk tanpa adanya proses. Proses yang dimaksud dalam hal ini adalah pengembangan sumber daya manusia dimana bertujuan untuk meningkatkan potensi-potensi yang dimiliki karyawan. Pelatihan sendiri merupakan

Korespondensi tentang artikel ini dapat dialamatkan kepada Ellyana Pratika melalui email: ellyanaeboypratika@ymail.com 
bagian yang penting dalam rangka peningkatan produktivitas.

Pelatihan menurut Sikula (dalam Mangkunegara, 2009:50) adalah suatu proses pendidikan jangka pendek yang menggunakan prosedur sistematis dan terorganisasi, pegawai non-manajerial mempelajari pengetahuan dan keterampilan teknis dalam tujuan yang terbatas. Pelatihan merupakan salah satu cara untuk memenuhi kebutuhan karyawan dalam mengembangkan diri. Pelatihan menghasilkan dan meningkatkan pengetahuan, keterampilan kemampuan, serta karakteristik lainnya yang dibutuhkan karyawannya dalam melakukan pekerjaan dan mewujudkan tujuan organisasi. Pelatihan karyawan dipandang sebagai media untuk meningkatkan pengetahuan keterampilan, dan keahlian karyawannya. Hal tersebut membuat pelatihan dipandang sebagai human investment.

Pelaksanaan pelatihan tidak cukup hanya sekali, tetapi dilakukan secara terus menerus dan sesuai dengan kebutuhan karyawan untuk bekerja secara profesional. Tujuannya agar wawasan mereka bertambah dan sudut pandangnya semakin meluas, serta mantap dalam mengolah pengetahuan dan keahlian mereka. Kesempatan untuk mengembangkan karir akan terbuka lebar jika karyawan meningkatkan pengetahuan, kemampuan, keterampilan, dan karakteristik lainnya. Keuntungan mengikuti pelatihan begitu banyak, namun tidak semua karyawan memiliki persepsi demikian. Menurut Krech (dalam Thoha, 2012:46) persepsi adalah proses kognitif yang dialami setiap orang dalam memahami lingkungannya, sehingga persepsi berkaitan erat dengan proses kognitif seperti ingatan dan berpikir.

Sebuah upaya yang dapat dilakukan untuk mendukung efektivitas pelatihan, perlu diperhatikan pendapat Schuler dkk, seperti yang dipaparkan oleh Irianto (2001:42) tentang faktor-faktor penting yang perlu diperhatikan dalam menyeleng- garakan program pelatihan dan pengembangan. Faktor-faktor tersebut yaitu faktor pelatih, faktor materi pelatihan, faktor metode pelatihan, faktor fasilitas pelatihan, faktor self-efficacy, faktor goal orientation, faktor training motivation.

Fakta yang terjadi di lapangan, peneliti menemukan banyak karyawan yang partisipasinya kurang dalam kegiatan pengembangan SDM yaitu pelatihan yang dilakukan oleh PT. Pelindo III. Seperti yang dikemukakan oleh kedua staf bagian SDM. Menurut beliau berbagai penyebab karyawan tidak mengikuti pelatihan adalah beberapa karyawan merasa bahwa pelatihan itu hanya teori dan mereka lebih baik mempelajari prakteknya langsung, ada yang beralasan tidak mengikuti pelatihan karena tugas-tugas dari kantor belum selesai dikerjakan dan menurut mereka lebih baik menyelesaikan tugas kantor daripada mengikuti pelatihan. Adanya berbagai persepsi mengenai pelatihan yang cenderung menganggap pelatihan itu tidak penting.

Menurut hierarki kebutuhan Maslow (dalam Robbins, 2003:126) terdapat lima kebutuhan yang dimiliki manusia. Pertama kebutuhan dasar yaitu kebutuhan fisiologis, kebutuhan keamanan, kebutuhan sosial dan kebutuhan penghargaan, serta kebutuhan tingkat tertinggi yaitu aktualisasi diri. Aktualisasi merupakan penggunaan semua bakat, pemenuhan semua kualitas dan kapasitas dalam diri seorang individu. Karyawan di suatu organisasi atau perusahaan yang mempunyai aktualisasi diri akan mampu mengoptimalkan kemampuan yang ada pada dirinya serta melakukan upaya ekstra dan melakukan hal-hal lebih daripada yang diharapkan. Karyawan yang mempunyai aktualisasi diri tinggi akan dapat menimbulkan suasana kerja yang dinamis, saling mendukung, selalu mempunyai kreatifitas yang tinggi dan selalu berfikir positif. Tingkat pencapaian aktualisasi diri pada karyawan organisasi atau perusahaan untuk mencapai tujuan perusa- 
haan dan pencapaian aktualisasi diri karyawan di berbagai perusahaan menunjukkan hasil yang signifikan.

Aktualisasi diri dalam dunia industri dapat dikembangkan melalui pelatihan yang diadakan oleh perusahaan. Karyawan dapat mengasah potensi dan keterampilan yang mereka miliki dengan mengikuti pelatihan. Karyawan yang mempunyai persepsi tinggi mengenai pelaksanaan pelatihan akan berpengaruh besar terhadap keberhasilan pelatihan. Mayoritas dari mereka menganggap bahwa potensi yang mereka miliki saat sudah cukup menjadi bekal dalam menyelesaikan tugas-tugas dengan baik. Pada kenyataannya memang tugas-tugas yang diselesaikan karyawan tersebut sangat baik, prestasi mereka juga dapat dibilang cemerlang tetapi ketertarikan mereka untuk mempelajari hal-hal baru, menambah ilmu serta pengetahuan itu sangat kurang. Mereka cukup nyaman dengan kemampuan yang mereka miliki saat ini. Hal tersebut menunjukkan bahwa mereka memiliki aktualisasi diri yang cenderung rendah. Pada dasarnya, kemampuan manusia akan terus meningkat apabila dilatih dan dikembangkan. Namun, setelah melakukan wawancara dengan beberapa karyawan PT Pelindo III Cabang Gresik mereka memiliki persepsi yang berbeda dengan tujuan pelatihan yang diselenggarakan perusahaan.

Faktanya yang terjadi di PT Pelindo III Cabang Gresik, ada salah satu karyawan yang dulunya bekerja sebagai staf bagian SDM mendapatkan promosi menjadi supervisor kemudian naik jabatan menjadi Manager SDM, umum, dan kesisteman. Hal tersebut dikarenakan persepsinya cukup tinggi mengenai pelaksanaan pelatihan serta prestasinya yang cemerlang. Beliau terus mengasah potensi-potensi yang dimilikinya. Keinginannya juga cukup tinggi untuk mendapatkan jabatan yang lebih tinggi. Peneliti melakukan wawancara dengan beliau, beliau mengatakan bahwa pelatihan yang diselenggarakan perusahaan selain berguna untuk pencapaian tujuan perusahaan juga berguna untuk pengembangan kualitas diri sendiri sehingga beliau merasa perlu untuk terus belajar melalui kegiatan pelatihan.

Peneliti menemukan pernyataan pada salah satu staf bagian Keuangan yang mengakui bahwa ia tidak memerlukan pelatihan karena malas untuk mengembangkan dirinya. Ia merasa bahwa kemampuan yang ia miliki cukup untuk menyelesaikan tugas-tugas kantor. Itulah penyebab mengapa ia malas mengikuti pelatihan yang diselenggarakan perusahaan. Ia mengaku sering mangkir dari pelatihan dengan alasan penyelesaian deadline tugas. Mayoritas karyawan PT Pelindo III Cabang Gresik mempunyai aktualisasi diri yang tinggi, hal tersebut terbukti dengan banyaknya karyawan yang telah di promosikan ke jabatan yang lebih tinggi. Hal tersebut nampak tidak berbanding lurus dengan persepsi mereka mengenai pelaksanaan pelatihan yang cenderung rendah.

Oleh karena itu penelitian ini bermaksud untuk mengetahui adanya hubungan antara aktualisasi diri dengan persepsi mengenai pelaksanaan pelatihan pada karyawan PT Pelindo III Cabang Gresik.

\section{Metode}

Penelitian ini menggunakan pendekatan kuantitatif korelasional yaitu penelitian yang bertujuan untuk meneliti sejauh mana variabel satu berkaitan dengan variabel lain berdasarkan koefisien korelasi (Azwar, 2012). Rancangan penelitian ini untuk mengetahui hubungan antara aktualisasi diri (X) sebagai variabel bebas dengan persepsi mengenai pelaksanaan pelatihan (Y) sebagai variabel terikat.

Sampel tryout penelitian ini berjumlah 35 karyawan PT Pelindo III Cabang Perak. Kuesioner yang disebar terdiri dari 70 aitem untuk skala aktualisasi diri dan 50 aitem untuk skala persepsi terhadap pelaksanaan pelatihan. Sedangkan 
populasi dalam penelitian ini adalah 46 karyawan PT Pelindo III Cabang Gresik. Pengambilan sampel menggunakan teknik populasi.

Penelitian ini menggunakan kuesioner dengan metode rating yang dijumlahkan atau lebih dikenal dengan penskalaan model Likert dengan pernyataan dalam lima kategori yaitu: Sangat Setuju (SS), Setuju (S), Tidak Setuju (TS), dan Sangat Tidak Setuju (STS). Sifat aitem-aitem dalam kuesioner tersebut dibuat bervariasi, mulai dari aitem yang bersifat favorable hingga yang bersifat unfavorable. Penelitian ini menggunakan 2 skala yaitu skala aktualisasi diri dan skala persepsi mengenai pelaksanaan pelatihan. Skala aktualisasi diri berisi 48 butir aitem, sedangkan skala persepsi terhadap pelaksanaan pelatihan berisi 45 butir aitem.

Teknik analisis data yang digunakan dalam penelitian ini adalah analisis product moment dari Pearson dengan menggunakan uji asumsi normalitas dan linieritas.

\section{Hasil dan Pembahasan}

Sebelum hipotesis penelitian ini diuji, terlebih dahulu dilakukan uji normalitas dan linearitas.

\section{Uji Normalitas}

Uji normalitas bertujuan untuk mengetahui apakah variabel aktualisasi diri dan persepsi terhadap pelaksanaan pelatihan yang digunakan untuk penelitian berdistribusi normal atau tidak. Nilai signifi-kansi variabel aktualisasi diri sebesar $p=0,173(p>0,05)$ dan nilai signifikanasi untuk variabel persepsi pelaksanaan pelatihan sebesar $\mathrm{p}=0,408$ ( $>>0,05)$. Hasil tersebut menunjukkan bahwa kedua variabel tersebut memiliki sebaran data yang berdistribusi normal karena nilai signifikansinnya lebih dari $0,05(\mathrm{p}>0,05)$.

\section{Uji linieritas}

Sedangkan uji liniearitas bertujuan untuk mengetahui apakah variabel aktualisasi diri dengan persepsi mengenai pelaksanaan pelatihan mempunyai hubungan yang linear atau tidak secara signifikan. Nilai signifikansi variabel aktualisasi diri dan persepsi mengenai pelaksanaan pelatihan sebesar $\mathrm{p}=0,014$. Hal ini berarti bahwa nilai signifikansi tersebut kurang dari 0,05 ( $\mathrm{p}<0,05)$. Hasil tersebut menunjukkan bahwa variabel aktualisasi diri dan persepsi mengenai pelaksanaan pelatihan memiliki hubungan linier.

\section{Uji hipotesis}

Hasil yang didapatkan dalam uji hipotesis menggunakan korelasi product moment dari Pearson adalah sebagai berikut. Tabel 3 menunjukkan bahwa korelasi antara variabel aktualisasi diri dan persepsi mengenai pelaksanaan pelatihan memiliki tingkat signifikansi $0.00(<0.05)$ dengan koefisien korelasi sebesar 0,651. Hasil uji analisis tersebut menghasilkan kesimpulan bahwa hipotesis alternatif yang menyebutkan bahwa "terdapat hubungan antara aktualisasi diri dengan persepsi mengenai pelaksanaan pelatihan pada karyawan PT Pelindo III Cabang Gresik" dapat diterima. Arah hubungan tersebut bersifat positif yang berarti makin tinggi aktualisasi diri makin tinggi pula persepsi terhadap pelaksanaan pelatihan dan sebaliknya. Hasil analisis tersebut juga menunjukkan bahwa variabel aktualisasi diri dan persepsi mengenai pelaksanaan pelatihan memiliki hubungan yang kuat karena memiliki koefisien korelasi 0,651.

Tabel 1. Hasil Analisis Product Moment 


\begin{tabular}{llcc}
\hline & & Aktualisasi diri & $\begin{array}{c}\text { Persepsi terhadap } \\
\text { pelaksanaan pelatihan }\end{array}$ \\
\hline Aktualisasi diri & Pearson Correlation & 1 & $.651^{\text {** }}$ \\
& Sig. (2-tailed) & & .000 \\
& $\mathrm{~N}$ & 46 & 46 \\
Persepsi terhadap & Pearson Correlation & $.651^{* * *}$ & 1 \\
pelaksanaan & Sig. (2-tailed) & .000 & 46 \\
pelatihan & $\mathrm{N}$ & 46 & \\
\hline
\end{tabular}

Hasil penelitian ini sejalan dengan penelitian Adhani (2013) yang menyebutkan bahwa pemenuhan kebutuhan akan aktualisasi diri merupakan tingkat kebutuhan tertinggi dari teori Maslow. Individu yang telah tercukupi dalam ke empat kebutuhan di bawahnya maka akan membutuhkan aktualisasi diri dimana ia diakui sebagai seseorang yang memiliki kontribusi penting atas sebuah perusahaan. Empat kebutuhan sebelumnya yaitu mulai dari kebutuhan fisiologis, kebutuhan akan keamanan dan rasa aman, kebutuhan untuk dicintai, dan kebutuhan untuk dihargai.

Karyawan yang memiliki aktualisasi diri yang tinggi akan terus mengasah kemampuan dan keterampilan-nya dengan mengikuti pelatihan. Hal tersebut sama dengan yang diungkapkan Maslow (dalam Alwisol, 2010:109) yang menyatakan aktualisasi diri adalah proses menjadi diri sendiri dan mengembangkan sifat-sifat dan potensi psikologis yang unik. Aktualisasi diri akan dibantu atau dihalangi oleh pengalaman dan oleh belajar. Aktualisasi diri akan berubah sejalan dengan perkembangan hidup seseorang. Ketika mencapai usia tertentu seseorang akan mengalami pergeseran aktualisasi diri dari fisiologis ke psikologis. Menurut Chaplin (2008:56) aktualisasi diri adalah kecenderungan untuk mengembangkan bakat dan kapasitas sendiri.

Hal tersebut tentunya sama dengan yang dikatakan Maslow (dalam Robbins, 2003:209) dimana aktualisasi diri merupakan dorongan untuk menjadi apa yang ia mampu, meliputi pertumbuhan, mencapai potensialnya dan pemenuhan diri. Jika seseorang atau dalam hal ini karyawan dapat mencapai ketiga aspek tersebut, maka dapat dikatakan mempunyai aktualisasi diri yang tinggi. Individu yang aktualisasinya tinggi akan terus mengasah kemampuan dan keterampilannya agar tujuannya tercapai. Sedangkan karyawan yang memiliki aktualisasi diri rendah cenderung malas untuk mengasah kemampuan dan keterampilan yang dimiliki, mereka kurang memedulikan potensi mereka, tidak mengembangkan kemampuan mereka, dan kurang memenuhi kebutuhan diri mereka sendiri. Pada dunia industri, kegiatan pelatihan yang diadakan oleh perusahaan merupakan salah satu fasilitas yang diberikan perusahaan untuk mengasah potensi karyawan.

Menurut penelitian Nurlaila (2006) Pelatihan dan motivasi kerja merupakan bagian yang penting dalam rangka peningkatan produktivitas. Pelatihan karyawan dipandang sebagai media untuk meningkatkan pengetahuan, keterampilan dan keahlian karyawannya, maka dari itu tak berlebihan pelatihan dipandang sebagai human investment. Kegiatan pelatihan tidak cukup hanya sekali, tapi dilakukan secara terus menerus, dan sesuai dengan kebutuhan karyawan untuk bekerja secara profesional. Tujuannya agar mereka tambah wawasan dan memperluas sudut pandangnya, serta mantap dalam mengolah pengetahuan dan keahlian mereka. Dalam perkembangannya, karyawan yang profesional hasil dari pelatihan, biasanya menjadi rebutan diantara perusahaan pesaing. Mereka biasanya sering diiming-imingi jabatan dan kompensasi yang lebih besar. 
Sehingga perusahaan perlu mengapresiasi mereka dengan kompensasi bukan uang, seperti penghargaan dan pengakuan.

Menurut Robbins (2003:134) persepsi didefinisikan sebagai suatu proses dimana individu mengorganisasikan dan menafsirkan kesan indera mereka agar memberi makna pada lingkungan mereka. Persepsi juga dipengaruhi oleh faktor pengalaman, proses belajar, cakrawala dan pengetahuan seseorang. Manusia mengamati obyek dengan inderanya sendiri yang diwarnai oleh nilai dari kepribadiannya, sedangkan obyeknya dapat berupa kejadian, ide atau situasi tertentu. Objekobjek yang dipersepsi dalam hal ini adalah faktor-faktor pelaksanaan pelatihan yang dikatakan oleh Schuler dkk (dalam Irianto, 2001:42) tentang faktor-faktor penting yang perlu diperhatikan dalam menyelenggarakan program pelatihan dan pengembangan. Sesuai dengan hasil penelitian menyebutkan bahwa terdapat hubungan positif antara kedua variabel.

Hal tersebut tentunya berkaitan dengan definisi pelatihan seperti dikemukakan oleh Sikula (Mangkunegara, 2009:50) adalah suatu proses pendidikan jangka pendek yang menggunakan prosedur sistematis dan terorganisasi, pegawai non-manajerial mempelajari pengetahuan dan keterampilan teknis dalam tujuan yang terbatas. Pelatihan merupakan salah satu cara untuk memenuhi kebutuhan karyawan dalam mengembangkan diri. Pelatihan menghasilkan dan meningkatkan pengetahuan, keterampilan kemampuan, serta karakteristik lainnya yang dibutuhkan karyawannya dalam melakukan pekerjaan dan mewujudkan tujuan organisasi.

Pembahasan yang telah dijelaskan di atas menunjukkan bahwa aktualisasi diri penting untuk diperhatikan oleh perusahaan. Karyawan yang memiliki aktualisasi diri yang tinggi akan terus mencapai keinginannya. Karyawan akan mengembangkan semua potensi yang dimiliki. Maka dari itu, perusahaan harus mening- katkan persepsi mengenai pelaksanaan pelatihan pada karyawan dengan cara meningkatkan aktualisasi diri karyawan. Peningkatan aktualisasi diri pada dasarnya dapat dicapai jika karyawan memenuhi ketiga aspek yaitu pertumbuhan, pemenuhan potensi diri, serta pencapaian potensi diri. Cara memperbaiki ketiga aspek tersebut adalah dengan beberapa indikator di dalamnya yaitu aspek pertumbuhan meliputi spontanitas, kesederhanaan, kewajaran, memusatkan diri pada masalah dan bukan pada diri sendiri, berfungsi secara otonom terhadap lingkungan sosial dan fisik, mengalami pengalaman-pengalaman puncak (peak experiences). Aspek pencapaian potensi diri meliputi orientasi secara realistik, struktur watak demokratis, dan kreatifitas. Sedangkan, aspek pemenuhan diri meliputi penerimaan umum atas kodrat, orang-orang lain dan diri sendiri, memiliki kebutuhan akan privasi dan independensi, apresiasi terhadap apapun yang dialami individu, minat sosial, hubungan antar pribadi yang kuat, mampu mengintegrasikan sarana dan tujuan, mempunyai selera humor yang tidak menimbulkan permusuhan, menentang konformitas terhadap kebudayaan.

Pada penelitian ini, tidak semua faktor yang mempengaruhi tingginya persepi mengenai pelatihan dapat diungkap. Faktor yang diungkap ialah aktualisasi diri. Penelitian ini memfokuskan pada hubungan antara aktualisasi diri dengan persepsi mengenai pelaksanaan pelatihan. Variabel-variabel lain juga dapat mempengaruhi persepsi mengenai pelaksanaan pelatihan antara lain motivasi kerja, produktifitas kerja, komitmen organisasi, dan sebagainya. Untuk penelitian lebih lanjut, seyogyanya, faktor-faktor yang diduga berpengaruh terhadap persepsi mengenai pelaksanaan pelatihan yang belum diamati tersebut diperhatikan.

\section{Simpulan}


Penelitian yang telah dilakukan pada karyawan PT Pelindo III Cabang Gresik menunjukkan bahwa aktualisasi diri memiliki nilai koefisien korelasi sebesar 0,651 . Hal ini dapat diketahui bahwa antara aktualisasi diri memiliki hubungan yang kuat dan positif atau berjalan searah dengan persepsi mengenai pelaksanaan pelatihan. Artinya, ada hubungan yang positif antara aktualisasi diri dengan persepsi mengenai pelaksanaan pelatihan. Hal ini berarti apabila semakin tinggi aktualisasi diri maka semakin tinggi pula persepsi mengenai pelaksanaan pelatihan yang dimiliki.

\section{Daftar Pustaka}

Adhani, A.R.. (2013). Pengaruh Kebutuhan Aktualisasi Diri dan Beban Kerja terhadap Prestasi Kerja Karyawan. Jurnal Ilmu Manajemen, 1(3), 1-11.

Alwisol. (2010). Psikologi Kepribadian. Malang : UMM Press

Azwar, S. (2012). Metode Penelitian. Cetakan XIII. Yogyakarta: Pustaka Pelajar.

Chaplin, J. P. (2008). Kamus Psikologi Lengkap. Jakarta: PT Raja Grafindo

Irianto, J. (2001). Tema-Tema Pokok Manajemen Sumber Daya Manusia. Surabaya: Insan Cendekiawan.
Mangkunegara, A.P.M. (2009). Evaluasi Kinerja SDM. Bandung: PT Refika Aditama

Nurlaila. (2006). Persepsi Karyawan Terhadap Pelatihan, Motivasi Kerja dan Produktivitas Pada PT Indosat, Tbk Divisi Cellular Customer Service. Jurnal Ekonomi.

Robbins, S. P., (2003), Organizational Behavior, Upper Saddle River New Jersey, Prentice-Hall, Inc

Thoha, M. (2012). Perilaku Organisasi Konsep Dasar Dan Aplikasinya. Jakarta: Rajawalipress. 